\title{
THE ELEVATION OF CEREBRAL HISTAMINE- $N$-AND CATECHOL-O-METHYL TRANSFERASE ACTIVITIES BY L-METHIONINE-dl- SULFOXIMINE ${ }^{1}$
}

\author{
R. A. SchatZ and O. Z. Sellinger \\ Laboratory of Neurochemistry, Mental Health Research Institute, University of Michigan Medical Center, \\ Ann Arbor, MI 48104, U.S.A.
}

(Received 11 November 1974. Accepted 9 January 1975)

\begin{abstract}
The administration of the convulsant, L-methionine-dl-sulfoximine (MSO), increased histamine $N$-methyl transferase (E.C. 2.1.1.8) (HMT) activity in rat and mouse brain and, to a lesser extent, catechol- $O$-methyl transferase (E.C. 2.1.1.6) (COMT) activity in rat brain. The duration of this effect was shortened by co-administration of L-methionine. The increased HMT activity was seen in 5 or 7 rat brain regions tested. L-Methionine administration had no effect on the activity of either enzyme. Partially purified HMT preparations from rat or guinea-pig brain exhibited no alterations in activity after the in vitro addition of MSO or L-methionine over a wide range of histamine and $S$-adenosyl-Lmethionine concentrations. Rat brain COMT was equally unaffected by MSO and $\mathrm{L}$-methionine. The in vitro inhibition of HMT and COMT by $S$-adenosyl-L-homocysteine was the same whether tested on preparations derived from MSO-treated or control animals. The data are discussed with respect to the possible involvement of aberrant methylation processes in the MSO-induced seizure.
\end{abstract}

THE ADMINISTRATION of the convulsant, L-methioninedl-sulfoximine, to rats results in a marked and regionally specific decrease of the brain levels of $S$ adenosyl methionine (SAM) (SCHATZ et al., 1973; SCHATZ \& SELLINGER, 1975). It has been known for some time that the joint administration of MSO and L-methionine prevents MSO-induced seizures (LoDIN \& KolouseK, 1958; SEllinger et al., 1968), and, more recently, we demonstrated that the MSO-induced depletion of cerebral SAM is also prevented under these conditions (SCHatz \& Sellinger, 1975). Two possible mechanisms which may account for the observed depletion of the SAM levels in brain after MSO are (a) an inhibition of the synthesis of SAM via an effect of MSO on ATP: L-methionine-S-adenosyl transferase (E.C. 2.5.1.6) and (b) a stimulation of the utilization of SAM by one or by several members of the large family of cerebral methyl transferase enzymes. Studies from our laboratory ( $\mathrm{SCHATZ}$ et al., 1973) have indicated that MSO fails to affect the synthesis of SAM either in vivo or in vitro, a finding which agrees with the observations of LOMBARDINI et al. (1970), who noted that MSO serves neither as a substrate nor as an inhibitor of the hepatic ATP: L-methionine-S-adenosyl transferase. In line with the

\footnotetext{
${ }^{1}$ Supported by grants from the United States Public Health Service MH 07417, NS 06294 and a grant from the Epilepsy Foundation of America.

Abbreviations used: MSO: L-Methionine-dl-sulfoximine. HMT: histamine- $N$-methyl transferase. COMT: catechol$O$-methyl transferase. SAM: $S$-adenosyl-L-methionine. SAH: S-adenosyl-L-homocysteine.
}

second of the above alternatives, DE RoBfrTis et al. (1967) described an increase of the cerebral catechol$O$-methyl transferase activity (E.C. 2.1.1.6) (COMT) after MSO, an observation which we undertook to explore in more detail, together with an examination of the effect of MSO on another methyl transferase enzyme of brain tissue, namely histamine- $N$-methyl transferase (E.C. 2.1.1.8) (HMT). The present report describes findings which lend support to the premise of an effect of MSO on the utilization of SAM, as evidenced by the selective elevation of HMT in mouse and rat brain after MSO, and, more specifically, in 5 out of 7 rat brain neuroanatomical regions. In addition, our results confirm and extend the original observation (DE RoBeRTIS et al., 1967) that MSO affects COMT in vivo and they also show that neither methyl transferase-stimulating effect of MSO is reversed when L-methionine is administered jointly with MSO. A preliminary report has appeared (Schatz et al., 1974a).

\section{MATERIAL AND METHODS}

Animals

Adult male Sprague-Dawley rats $(120-200 \mathrm{~g})$ and adult male Swiss Webster mice (25-32 g) were obtained from Spartan Research Animals, Inc. (Haslett, Michigan). Adult male Hartley guinea-pigs $(425-550 \mathrm{~g})$ were from Camm Research (Wayne, New Jersey).

\section{Materials}

Histamine dihydrochloride, 3,4-dihydroxybenzoic acid, 3-methoxy-4-hydroxybenzoic acid, $S$-adenosyl-L-homocysteine and L-methionine-dl-sulfoximine (MSO) were 
obtained from Sigma Chemical Co., St. Louis, Missouri; L-methionine, from ICN Nutritional Biochemicals (Cleveland, Ohio); 1-methylhistamine dihydrochloride, from Calbiochem (La Jolla, California); S-adenosyl-L-methionine chloride, from P-L Biochemicals, Inc. (Milwaukee, Wisconsin); radioactive $S$-adenosyl-L-[methyl $\left.-{ }^{14} \mathrm{C}\right]$ methionine (specific activity $52-57 \mathrm{mCi} / \mathrm{m}$-mole, from New England Nuclear (Boston, Massachusetts); PPO and dimethyl POPOP, from Packard Instrument Co., Inc. (Downers Grove, Illinois) and silica gel TLC plates (with fluorescent indicator) from EM Laboratories (Elmsford, New York). $N^{\prime}$-methylhistamine and $N^{\prime}, N^{\prime}$-dimethylhistamine were generously provided by Dr. W. A. M. Duncan, Smith, Kline and French Laboratories, Ltd., Welwyn Garden City, Herts, England.

Drug treatment and tissue preparation for in vivo assays

Rats or mice were injected intraperitoneally with saline $(10 \mathrm{ml} / \mathrm{kg})$, methionine $(4.7 \mathrm{~m}-\mathrm{mole} / \mathrm{kg})$, MSO $(0.94 \mathrm{~m}-$ mole $/ \mathrm{kg}$ ) or both MSO and methionine, 1, 3 and $6 \mathrm{~h}$ prior to sacrifice by decapitation. For regional analyses of HMT, rat brains were rapidly dissected on ice (GLowINSKI \& IVERSEN, 1966). Whole rat or mouse brain and rat brain regions were homogenized in 5-10 vol. of ice-cold salineTriton X-100 (0-1\% v/v) (TAYLOR \& SNYDER, 1972) and the homogenates were centrifuged at $50,000 \mathrm{~g}$ for $10 \mathrm{~min}$. Aliquots of these supernatants were assayed for HMT or COMT activity (see below).

\section{Tissue preparation for in vitro experiments}

Whole rat or mouse brain was homogenized in 5-10 vol. of ice-cold $0.32 \mathrm{~m}$ sucrose or saline-Triton X-100 $(0.1 \%)$ and $50,000 \mathrm{~g}$ supernatants were prepared as deseribed in the above section. For some experiments, HMT was partially purified from rat or guinea-pig brain by the procedure of BRown et al. (1959).

\section{Analytical}

COMT was determined according to MCCAMAN (1963) as modified by Porcher \& HeLLer (1972) with 3,4-dihydroxybenzoic acid as substrate. After a $30 \mathrm{~min}$. incubation period the reaction was stopped by the addition of $0.2 \mathrm{ml}$ of $3 \mathrm{M} \mathrm{HCl}$. Ethyl acetate $(6 \mathrm{ml})$ was added, the tubes shaken for $10 \mathrm{~min}$, centrifuged at $2000 \mathrm{rev} . / \mathrm{min}$ (GLC-1, Sorvall, Inc., Newton, Connecticut) for $10 \mathrm{~min}$ and $4 \mathrm{ml}$ aliquots of the organic phase were used to measure radioactivity. The reaction product migrated identically with authentic 3-[methyl- $\left.{ }^{14} \mathrm{C}\right]$ methoxy-4-hydroxybenzoic acid on silica gel TLC plates in benzene:propionic acid:water (2:2:1) (ARMSTRONG et al., 1956). Compounds were identified by means of diazotized sulfanilic acid spray (AMES \& MITCHELL, 1952), ninhydrin (0-25\% in acetone) spray and the ultraviolet quenching reaction (SALvatore et al, 1971). Recovery of 3-[methyl- $\left.{ }^{14} \mathrm{C}\right]$ methoxy-4-hydroxybenzoic acid from ethyl acetate was $85 \%$. HMT was assayed according to SNYDER \& AXELROD (1965). Authentic [methyl- ${ }^{14} \mathrm{C}$ ] methylhistamine was prepared by this method, and routinely $10^{-5} \mathrm{M}$ histamine was used in the assay, higher concentrations proving strongly inhibitory. The concentration of SAM was $3.2 \times 10^{-5} \mathrm{M}$. The nature of the product was investigated and found to be identical with 1-methylhistamine, by co-chromatography with the authentic substance using silica gel TLC or paper (Whatman No, 1) chromatography in ethanol:20\% ammonia:water $(10: 1: 1)$, ethanol:diethyl ether: $25 \%$ ammonia:water $(8: 10: 1: 2)$ and $n$-butanol:ethyl acetate:water $(1: 1: 1)$.
Compounds were identified using the ultra-violet quenching reaction and ninhydrin $(0.25 \%$ in acetone $)$ or iodine $\left(1 \%\right.$ in ethanol) sprays. The recovery of [methy]- $\left.{ }^{14} \mathrm{C}\right]$ methylhistamine from the organic phase was $50 \%$. All enzyme activity values were corrected accordingly. For counting, $4 \mathrm{ml}$ aliquots of the organic phase were transferred to vials containing $2 \mathrm{ml}$ of ethanol and $10 \mathrm{ml}$ of scintillant $(0.4 \%$ PPO and $0.01 \%$ dimethyl POPOP in toluene) and the radioactivity was measured in a liquid scintillation counter (Unilux II, Nuclear Chicago). Counting efficiency was determined by the channels ratio technique.

Protein was measured in triplicate by the method of LowRy et al. (1951) using bovine serum albumin as the protein standard.

\section{Statistical analysis}

Statistical differences between drug-treated groups and corresponding saline-treated animals were evaluated by the Student $t$-test.

\section{RESULTS}

\section{The effect of MSO on HMT in vivo}

The administration of MSO produced a timedependent increase of whole brain HMT specific activity which was maximal $(25 \%)$ at $6 \mathrm{~h}$ (Fig. 1). HMT activity was also significantly increased at 1 and $3 \mathrm{~h}$ after MSO as well as after MSO + L-methionine, but not after L-methionine alone. Since the HMT activity of rat brain is much lower than that of mouse brain (SCHAYER \& REILLY, 1973), it appeared possible that the effect of MSO on HMT could only be demonstrable in a species with low HMT activity. To test this, mouse brain HMT was assayed 1, 3 and $6 \mathrm{~h}$ after MSO and, as was true for rat brain, a timerelated increase of its specific activity, with a maximum of $20 \%$ at $6 \mathrm{~h}$, was demonstrated (Fig. 2).

The previously uncovered regional specificity of the MSO-induced depletion of cerebral SAM levels

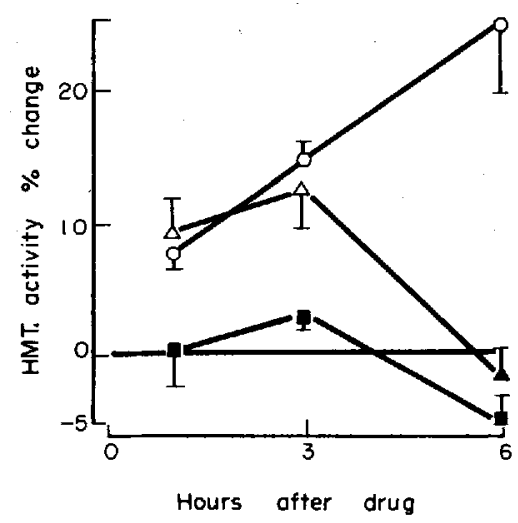

FIG. 1. Effect of methionine or methionine sulfoximine on rat brain histamine- $N$-methyltransferase activity. $\square-$ methionine $(4.7 \mathrm{~m}-\mathrm{mol} / \mathrm{kg})$, o-MSO $(0.94 \mathrm{~m}-\mathrm{mol} / \mathrm{kg})$, $\triangle-\mathrm{MSO}+$ methionine. Each point represents the \% change (mean \pm S.E.M.) of from 5-7 rats in enzyme activity compared to the corresponding saline-treated group. Mean control values varied from $1.69 \pm 0.05$ to $1.95 \pm 0.052 \mathrm{~m} \mu$ mole methylhistamine/mg protein/h. Open symbols denote a significant difference from saline values at the 0.05 level using the Student $t$-test. 


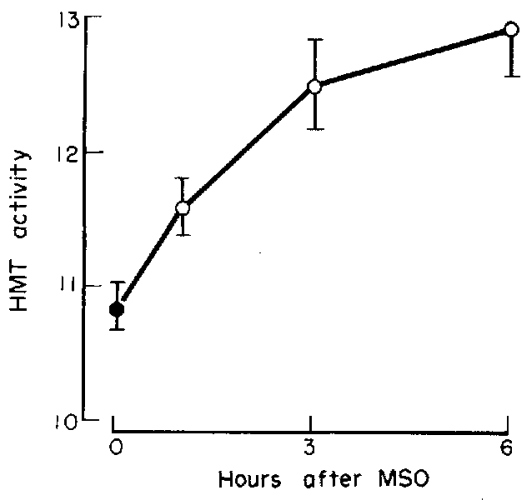

FIG. 2. Effect of methionine sulfoximine on mouse brain histamine- $N$-methyltransferase activity. - saline $(10 \mathrm{ml} /$ $\mathrm{kg})$; O-MSO $(0.94 \mathrm{~m}-\mathrm{mol} / \mathrm{kg})$. Values arc expressed as $\mathrm{m} \mu$ mole methyl histamine/mg protein $/ \mathrm{h}$ and represent the mean \pm S.E.M. of 6-7 mice. Open symbols denote a significant difference from saline values at the 0.05 level using the Student $t$-test.

(SCHATZ \& SelLINGER, 1975) prompted us to examine the possibility of a similar regional specificity of the MSO effect on rat brain HMT. Table 1 shows that the specific activity of HMT in control brains varied over a 5 -fold range from a low of $0.63 \mathrm{nmol}$ of methylhistamine/mg of protein/h in the cerebellum to a high of $3.00 \mathrm{~m} \mu$ mole of methylhistamine $/ \mathrm{mg}$ of protein $/ \mathrm{h}$ in the hypothalamus. While no significant effects of MSO were noted at I h, HMT activity was signifcantly increased in all regions except the midbrain and the hypothalamus at $3 \mathrm{~h}$. At $6 \mathrm{~h}$ the MSO-elicited increase remained significant in the cerebellum, the brainstem, the cerebral cortex and the hippocampus, while it ceased to be significant in the striatum (Fig. 3).

\section{The effect of MSO on COMT in vivo}

The results of an investigation of the effects of MSO on whole rat brain COMT activity are shown in Fig. 4 . The activity was moderately, albeit signif-cantly $(8 \%)$, increased at $3 \mathrm{~h}$. The joint administration of MSO + L-methionine also increased COMT activity at 1 and $3 \mathrm{~h}$, whereas, as was the case with HMT, injections of L-methionine alone had no effect (Fig. 4).

\section{Attempts to demonstrate effects on HMT in vitro}

Two scts of experiments were conducted. (A) HMT

TABLE 1. HMT ACTIVITY IN REGIONS OF THE RAT BRAIN

\begin{tabular}{ll}
\hline \multicolumn{1}{c}{ Brain Region } & HMT \\
\hline Cerebellum & $0.63 \pm 0.04$ \\
Brainstem & $1.75 \pm 0.08$ \\
Striatum & $2.67 \pm 0.09$ \\
Hippocampus & $2.71 \pm 0.09$ \\
Cortex & $2.74 \pm 0.10$ \\
Midbrain & $2.91 \pm 0.14$ \\
Hypothalamus & $3.00 \pm 0.15$
\end{tabular}

Values are expressed as $\mathrm{m} \mu \mathrm{mol}$ methylhistamine $/ \mathrm{mg}$ protein $/ \mathrm{h}$ and are means \pm S.E.M. of 7 rats. was purified from untreated rat or guinea-pig brains and the effect of several substances on its activity was tested. (B) HMT was purified in parallel from untreated rats and from animals injected with a convulsant dose of MSO $3 \mathrm{~h}$ prior to death and the effects of a number of substances on both activities were compared in vitro.

(A) The following negative findings were made: MSO $\left(10 x^{-8} \mathrm{M}-10 \times^{-2} \mathrm{M}\right)$ had no effect on partially purified (3-fold) guinea-pig or rat (4-5 fold) HMT whether assayed in the presence of optimal $\left(1 \times 10^{-5} \mathrm{M}\right)$ or suboptimal (below $1 \times 10^{-6} \mathrm{M}$ or above $1 \times 10^{-4} \mathrm{M}$ ) concentrations of histamine with SAM at $3.2 \times 10^{-5} \mathrm{M}$ or, alternatively, over the range $5.7 \times 10^{-6} \mathrm{M}-3.2 \times 10^{-5} \mathrm{M}$ SAM and with histamine at $1 \times 10^{-5} \mathrm{M}$. The extent of inhibition of purified rat HMT by $S$-adenosylhomocysteine (BAUDRY et al., 1973) which amounted to about $45 \%$ at $10^{-5} \mathrm{M} \mathrm{SAH}$ and to about $95 \%$ at $10^{-3} \mathrm{M}$ SAH and which was independent of the concentration of histamine varying between $1 \times 10^{-4} \mathrm{M}$ and $1 \times 10^{-6} \mathrm{M}$, was not altered by $10^{-3}-10^{-5} \mathrm{M}$ MSO; similarly $10^{-3} \mathrm{M}$ MSO failed to influence the competitive inhibition by $1 \times 10^{-5} \mathrm{M}$ SAH of the rat brain HMT with respect to SAM when assayed in the presence of $1 \times 10^{-5} \mathrm{M}$ histamine and over a range of SAM concentrations extending from a low of $6.4 \times 10^{-7} \mathrm{M}$ (HMT inhibition: $86^{\circ} \%$ ) to a high of $6.4 \times 10^{-5} \mathrm{M}$ (HMT inhibition:24.5\%).

(B) Several attempts were made to show differences between the HMT of control and MSO-treated animals: (a) Dialysis of high-speed supernatants obtained from control brains did not result in increases of HMT activity; (b) There was no difference in sensitivity to inhibition by SAH $\left(5 \times 10^{-6} \mathrm{M}-5 \times 10^{-5} \mathrm{M}\right)$ between the HMT prepared from control and MSOtreated brains, irrespective of the medium $(0.32 \mathrm{M}$ sucrose vs saline-Triton X-100, TAYLOR \& SNYDER, 1972) in which the brain homogenate was prepared or of the storage conditions $\left(4^{\circ} \mathrm{C}\right.$ vs $\left.-70^{\circ} \mathrm{C}\right)$ under which the appropriate fractions were kept.

\section{Attempts to demonstrate effects on COMT in vitro}

Sucrose $(0-32 \mathrm{M})$ or Triton X-100 (0-1\%) supernatants of mouse and rat brain were prepared (BRocH $\&$ FonNuM, 1972) and COMT activity was measured in the presence of $10^{-5}$ and $10^{-3} \mathrm{M}$ MSO or $L$ methionine. No effect of these substances on the activity was noted, although, somewhat contrary to the observations of BROCH \& FONNUM (1972), COMT activity in the $50,000 \mathrm{~g}$ sucrose supernatants of both mouse and rat brains was consistently higher (about $30 \%$ ) than that associated with saline- $0.1 \%$ Triton X-100 supernatants prepared in parallel. Moreover, there was no difference in the sensitivity of COMT toward SAH inhibition (COWARD et al., 1972) between untreated and MSO-treated $(3 \mathrm{~h})$ animals.

\section{DISCUSSION}

The administration of MSO, previously shown to modulate the cerebral levels of methionine (TEws \& Stone, 1964; Ghittoni \& Sellinger, 1970) and to 


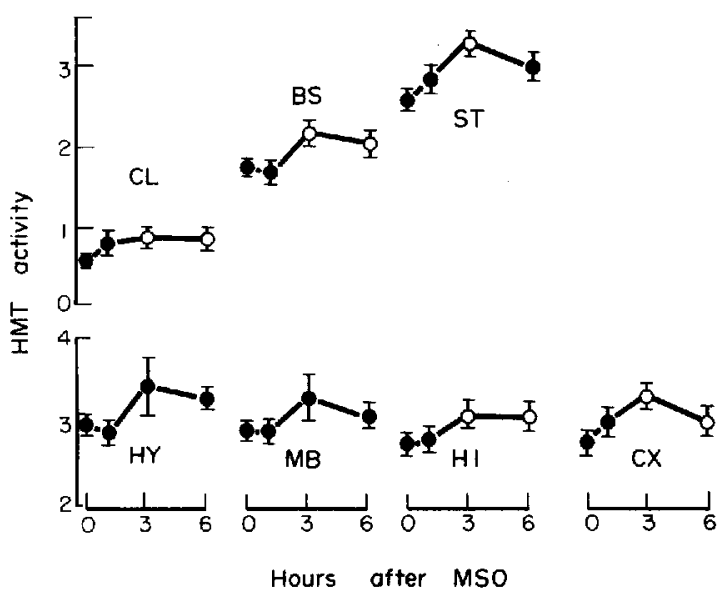

FIG. 3. Effect of methionine sulfoximine on histamine- $N$ methyltransferase activity in rat brain regions. - saline $(10 \mathrm{ml} / \mathrm{kg}), \quad$-MSO $(0.94 \mathrm{~m}-\mathrm{mol} / \mathrm{kg})$. CL-cerebellum, BS-brainstem, ST-striatum, HY-hypothalamus, MB-midbrain, HI-hippocampus, $\mathrm{CX}$-cortex. Values are expressed as $\mathrm{m} \mu$ mole methylhistamine/mg protein $/ \mathrm{h}$ and represent the mean \pm S.E.M. of regions from 6-7 rats. Open symbols denote a significant difference from control values at the 0.05 level using the Student $t$-test.

cause marked and region-specific reductions of cerebral SAM levels (SCHATZ \& SELLINGER, 1975) also results in a time-dependent elevation of the specific activities of two cerebral methyltransferases, HMT and COMT (Figs. 1-4). Of interest was the finding that the elevation of HMT occurred only in those brain regions in which the specific activity of HMT was below a value of 2.75 (Table 1), i.e. it did not involve the midbrain and the hypothalamus. The HMT specific activity values reported in Table 1 are higher than those previously reported by TAYLOR \& SNYDER (1972) and, more recently, by SCHWARTZ et al. (1973). This is because different tissue preparations and histamine concentrations were used in the various determinations. Thus, TAYLOR \& SNYDER (1972) compared the specific activity of HMT in homogenates of seven regions of the rat brain and found the highest value, $1.05 \mu \mathrm{mole} / \mathrm{h} / \mathrm{g}$ of protein, in the hypothalamus. A value of $2.08 \mu \mathrm{mol} / \mathrm{h} / \mathrm{g}$ of protein was obtained, however, when the assay was carried out on the $50,000 \mathrm{~g}$ hypothalamic supernatant and in the presence of $10^{-5}$ histamine. In agreement with the observations of SCHWARTZ et al. (1973), the specific activity of HMT in the spinal cord of the rat was found to be about $40 \%$ lower than that of whole brain (Schatz, R. A. \& Sellinger, O. Z., unpublished observations). Thus, despite some fluctuations in HMT specific activity as determined in different laboratories, its relative regional distribution reflects uniform agreement, with the hypothalamus exhibiting the highest, and the cerebellum the lowest values.

Comparing the regional effects of $\mathrm{MSO}$ on the levels of cerebral SAM (SchatZ \& SELlinger, 1975) with those on HMT (Fig. 3) reveals that in both instances the hypothalamus and the midbrain remained largely unaffected, while, on the contrary, all other regions, with the exception of the brainstem in which HMT was elevated in the face of unchanged SAM, showed reduced SAM levels concomitantly with an elevation of the HMT activity. In addition (Figs. 1 and 4), despite the marked increases of cerebral methionine (DANIEL \& WAISMan, 1969; Ghittoni \& SELLINGER, 1970) and of SAM (BALDESSARINI, 1966; RuBIN et al., 1974; SCHATZ \& SELLINGER, 1975) consequent to its administration, L-methionine failed to affect cerebral HMT and COMT, suggesting that the absolute level of SAM in brain is not a direct factor in the regulation of methyl transfer reactions in this organ. Similarly, we recently also established (Schatz, R. A., Goldfarb, M. \& Sellinger, O. Z., unpublished observations) that the injection of massive doses of L-histidine (TAYLOR \& SNYDER, 1972) alone, shortly before or jointly with MSO, also fails to affect the existing levels of cerebral HMT, suggesting, in turn, that the activity of this particular methyl transferase is not directly modulated by, or dependent on, prevailing tissue levels of histamine or, for that matter, of its precursor, L-histidine. Finally, Fig. 1 illustrates the competitive nature of the MSO-methionine interaction, clearly evidenced by the more rapid return of HMT and COMT levels to control values after the joint administration of MSO + methionine than after the administration of MSO alone. It is highly likely that the observed reversal of the MSO effect on HMT and COMT underlies the markedly reduced entry of MSO into the brain itself as well as into its cellular (SELLINGER et al., 1971) and subcellular (LAMAR \& Sellinger, 1965; GHitToni et al., 1970; SCHATZ et al., 1974b) compartments, which ensues when the natural amino acid and its unnatural convulsant derivative are administered together.

It has been suggested that tissue SAH levels regulate the activity of several methyl transferases, including HMT (ZAPPIA et al., 1969; BAUDRY et al., 1973)

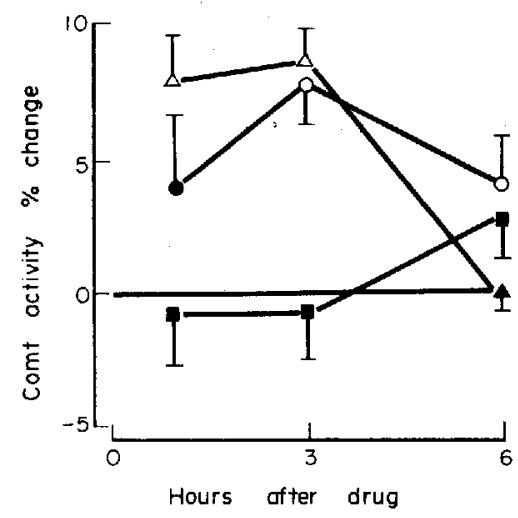

FIG. 4. Effect of methionine or methionine sulfoximine on rat brain catechol- $O$-methyltransferase activity. $\square$-methionine $(4.7 \mathrm{~m}-\mathrm{mol} / \mathrm{kg}), \quad$ - $\mathrm{MSO}(0.94 \mathrm{~m}-\mathrm{mol} / \mathrm{kg}), \Delta-$ $\mathrm{MSO}+$ methionine. Each point represents the $\%$ change (mean \pm S.E.M. of 4-7 rats) in enzyme activity compared to the corresponding saline-treated group. Mean control values varied from $10.4 \pm 0.26$ to $11.2 \pm 0.07 \mathrm{~m} \mu \mathrm{mol} 3$ methoxy-4-hydroxybenzoic acid/mg protein/h. Open symbols denote a significant difference from saline values at the 0.05 level using the Student $t$-test. 
and COMT (DEGUCHI \& Barchas, 1971; COWARD et al., 1972); we reasoned therefore that MSO may be effective in altering the sensitivity of these enzymes toward SAH in vitro. Our efforts to gain evidence for this supposition were unsuccessful, however, as we found no circumstances under which HMT and COMT inhibition by SAH could be diminished by MSO. As a result, it is difficult to reconcile the in vitro and the in vivo findings, as depicted in Figs. $1-4$, except by assuming that the MSO effect in vivo is indirect and dependent on the structural integrity of the tissue and the intactness of membrane-bound intracellular compartments housing molecules such as SAM (JUDES \& JACOB, 1972), SAH, HMT (SNYDFR et al., 1974) and COMT (PorChir \& Heller, 1972).

We have considered two other explanations for the observed MSO-induced increase of HMT: (1) MSO elicits the methylation of histamine to $N^{\prime}$-methyland/or $N^{\prime} N^{\prime}$-dimethylhistamine, two known activators of HMT in vitro (BARTH et al., 1973), $N^{\prime}$-methylhistamine, in addition, serving as a substrate for the HMT of the pig antrum mucosa (BARTH et al., 1973). A preliminary search for these substances has not been successful to date as no evidence for their formation in vitro by the HMT of MSO-treated, but not by that of control animals, could be obtained. The alternate possibility, namely the formation of $N^{\prime}$ methylhistamine and $N^{\prime}, N^{\prime}$-dimethylhistamine in brain after MSO remains to be tested. (2) MSO causes an accelerated metabolism of SAH via activation of adenosylhomocysteinase (S-adenosylhomocysteine hydrolase, E.C. 3.3.1.1), an enzyme known to be engaged in the regulation of several other methyl transferases including hepatic COMT (DEGUCHI \& BARCHAS, 1971). Brains of MSO-treated animals would thus contain less than normal amounts of $\mathrm{SAH}$, the regulation of HMT levels by SAH would be temporarily relieved and hence HMT activity levels would rise to the observed higher than normal values.

It is tempting to extend the relevance of the above considerations to help explain the convulsant properties of MSO. It is possible that 'abnormal' methylated substances such as, for example, $N^{\prime}$-methyl- and/or $N^{\prime}, N^{\prime}$-dimethylhistamine or other as yet unidentified methylated amines may be the actual causative agents of the seizure. Alternatively, if increased breakdown of excess SAH is involved as a mechanism to return the MSO-perturbed cellular SAM/SAH ratios to control values, homocysteine, a convulsant agent whose action results in MSO-like seizures (SPRINCE et al., 1969), and/or homocysteic acid, a powerful CNS excitant (CurTis et al., 1972) could be produced at selected sensitive sites in amounts sufficient to trigger uncontrolled neuronal firing.

\section{REFERENCES}

Ames B. N. \& Mitchell H. K. (1952) J. Am. chem. Soc. 74, 252-253.

ARMStrong M. D., SHAW K. N. F. \& Wall P. E. (1956) J. hiol. Chem. 218, 293-303.

Baldessarini R. J. (1966) Biochem. Pharmac. 15, 741-748.
Barth H., Lorenz W. \& NiEMEyer I. (1973) Hoppe-Seyler's Z. physiol. Chem. 354, 1021-1026.

Baudry M., Chast F. \& Schwartz J.C. (1973) J. Neurochem. 20, 13-21.

Broch O. J. JR. \& Fonnum F. (1972) J. Neurochem. 19, 2049-2055.

Brown D. B., TOMCHICK R. \& AXELROD J. (1959) $I$. biol. Chem. 234, 2948-2950.

Coward J. K., D'Urso-Scott M. \& Swhet W. D. (1972) Biochem. Pharmac. 21, 1200-1203.

Curtis D. R., Duggan A. W., Felix D., Johnson G. A. R., Tebecis A. K. \& Watkins J. C. (1972) Brain Res. 41, 283-301.

Daniel R. G. \& Waisman H. A. (1969) J. Neurochem. 16. $787-795$.

De Robertis E., Sellinger O. Z., Rodriguez De Lores Arnaiz, G., Alberici M. \& Zieier L. M. (1967) J. Neurochem. 14, 81-89.

Deguchi T. \& Barchas J. (1971) J. biol. Chem. 246, 3175 3181.

Ghittoni N. E., Ohlsson W. G. \& Sellinger O. Z. (1970) J. Neurochem. 17, 1057-1068.

Ghitroni N. E. \& Sellinger O. Z. (1970) Pharmac. Res. Commun. 2, 117-120.

GLOWINSKI J. \& IVERSEN L. L. (1966) J. Neurochem. 13, 655-669.

Jubls C. \& JACOB M. (1972) FEBS Letters 27, 289 292.

Lamar C. JR. \& Sellinger O. Z. (1965) Biochem. Pharmac. 14, 489-506.

Lodin Z. \& Kolousek J. (1958) Physiologia bohemoslov. 7, 292-298.

Lombardini J. B., Coulter A. W. \& Talalay P. (1970) Molec. Pharmac. 6, 481-499.

Lowry O. H., Rosebrough N. J., Farr A. L. \& Randall R. S. (1951) J. biol. Chem. 193, 265-275.

McCaman R. E. (1965) Life Sci. 4, 2353-2359.

Porcher W. \& Heller A. (1972) J. Neurochem. 19, 19171930.

Rubin R. A., Ordoñez L. A. \& WURTMAN R. J. (1974), J. Neurochem. 23, 227-233.

Salvatore F., Utili R., Zappia V. \& Shapiro, S. K. (1971) Analyt. Biochem. 41, 16-28.

Schatz R. A., Diez-Altares M. C. \& Sellinger O. Z. (1973) Trans. Am. Soc. Neurochem. 4, 74.

Schatz R. A., Ashcraft E. A. \& Sellinger O. Z. (1974a) Trans. Am. Soc. Neurochem. 5, 184.

Schatz R. A., Harris R. \& Sellinger O. Z. (1974b) The Pharmacologist 16, 256.

Schatz R. A. \& Sellinger O. Z. (1974) J. Neurochem. 24, 63-66.

Schayer R. W. \& Reilly M. A. (1973) J. Pharmac. exp. Ther. 187, 34-39.

Schwartz J.-C., Baudry M., Chast F., Pollard H. \& Bischorf S. (1973) in Central Nervous System-Studies on Metabolic Regulation and Function (Genazzani E. \& Herken H., eds.) pp. 172-184. Springer-Verlag, New York.

Sellinger O. Z., Azcurra J. M. \& Ohlsson W. G. (1968) J. Pharmac. exp. Ther. 164, 212-222.

Sellinger O. Z., Azcurra J. M., Johnson D. E., Ohlsson W. G. \& Lopn Z. (1971) Nature, London New Biology 230, 253-256.

SNyder S. H. \& AXELRod J. (1965) Biochim. biophys. Acta $111,416-421$.

SNyder S. H., Brown B. \& Kuhar M. J. (1974) J. Neurochem. 23, 37-45. 
Sprince, H., Parker C. M. \& Josephs J. A. JR. (1969) Tews J. K. \& Stone W. E. (1964) Biochem. Pharmac. 13, Agents and Actions 1, 9-13. 543-545.

TAYLOR K. M. \& SNYder S. H. (1972) J. Neurochem. 19, ZAPPIA V., ZYDek-Cwick C. R. \& SCHLENK F. (1969) J. $1343-1358$ biol. Chem. 244, 4499-4509. 